\title{
The role of some elicitors in inducing chilling stress resistance in apricot fruit
}

\author{
${ }^{1,2}$ A. Ezzat - ${ }^{1}$ Zoltán Szabó- ${ }^{3}$ A. K. Ammar \\ ${ }^{1}$ University of Debrecen Faculty of Agricultural and Food Sciences and Environmental Management, \\ Institute of Horticulture, Debrecen, Hungary \\ ${ }^{2}$ Horticulture Department, Faculty of Agriculture, University of Kafr El-Sheikh, Egypt \\ ${ }^{3}$ Food Science and Technology Department, Faculty of Agriculture, University of Kafr El-Sheikh, Egypt \\ ezz.deb12@gmail.com
}

\begin{abstract}
SUMMARY
This study aimed to study the role of $2 \mathrm{mM}$ salicylic acid and $0.2 \mathrm{mM}$ methyl Jasmonic acid in reducing the chilling injuries on two different apricot varieties fruits (Bergarauge and Flavor cot). These treatments were applied for apricot fruit directly after harvest after measuring the zero time data. Then the fruit were stored at $1{ }^{\circ} \mathrm{C}$ for three weeks and were examined 7 day periodically, other group of fruit was stored at $1{ }^{\circ} \mathrm{C}$ for 15 days then transport to room temperature and examined after 4 and 8 days. The fruit samples were collected at each examination time, and the measurements containing the fruit firmness $\left(\mathrm{Kg} \mathrm{cm}^{-2}\right)$, chilling and decay index, membrane electrolyte leakage, total phenol content and phenylalanine ammonia lyase mechanism (PAL) activity. The results showed that there are no obvious differences between the tested varieties and the differences may back to genetic variations and they took the same trend for most of measurement after treated with SA and MJ. SA and/or MJ treated fruit achieved low percentage of fruit softening in comparison to water treated fruit. At the same time the chilling and decay index showed that the SA and/or MJ reduced the decay or breakdown symptoms in either tested varieties. The treated fruit with those elicitor help the fruit to keep about stable phenol content while water treated fruit lose the phenol content sharply at early storage and this stable level of phenol my because of the ability of those chemical to raise PAL activity in treated fruit.
\end{abstract}

Keywords: apricot fruit, chilling injuries, salicylic acid, methyl jasmonic acid, PAL

\section{ÖSSZEFOGLALÁS}

A tanulmány célja $2 \mathrm{mM}$ szalicilsav és $0.2 \mathrm{mM}$ metil-jázmonsav hatásának vizsgálata két sárgabarack fajta (Bergarauge és Flavor cot) fagyási sérüléseinek enyhitésében. A kezeléseket közvetlenül szedés után végeztük. Ezután a gyümölcsöt három hétig $1^{\circ} \mathrm{C}$-on tartottuk és 7 napig vizsgáltuk. A sárgabarack másik vizsgált csoportját 15 napig tartottuk $1{ }^{\circ} \mathrm{C}$-on, majd szobahömérsékleten tárolva a 4. és a 8 . napon vizsgáltuk. Mintát vettünk a gyümölcsökböl minden egyes vizsgálat során és a következö tényezöket elemeztük: keménység (Kg/ $\left.\mathrm{cm}^{2}\right)$, fagyási és romlásindex, elektrolitszivárgás a sejtmembránon, összes fenoltartalom, illetve fenilalanin ammónia-liáz (PAL) aktivitás. Az eredmények rámutattak, hogy nincs lényegi különbség a vizsgált fajták közt, illetve az esetleges különbségek genetikai gyökerüek lehetnek és hasonló tendenciát mutattak a szalicilsav és a metil-jázmonsav kezeléseket követöen. A szalicilsavval és/vagy metil-jázmonsavval kezelt gyümölcs alacsony szintü puhulást mutatott a vizzel kezelt gyümölcshöz képest. Ugyanakkor a fagyási és romlásindex alapján megállapitottuk, hogy a szalicilsavas és/vagy metil-jázmonsavas kezelés csökkentette a romlást és a bomlási folyamatokat mindkét vizsgált fajtában. Az elicitorok hatására a gyümölcs képes volt stabil szinten tartani a fenoltartalmat, míg a vizzel kezelt gyümölcs már a tárolási idöszak elején rohamosan veszitett fenoltartalmából. Ennek oka az lehet, hogy a kezeléshez használt anyagok hatására a gyümölcs növelni tudja PAL aktivitását.

Kulcsszavak: sárgabarack, fagyási sérülések, szalicilsav, metil-jázmonsav, PAL

\section{INTRODUCTION}

Apricot (Prunus armeniaca L.) is classified under the Prunus species of Prunoidae sub-family of the Rosaceae family of the Rosales group. Apricot has an important place in human nutrition, and can be used as fresh, dried or processed fruit. Fruit quality is essential for the acceptance of apricot cultivars by consumers, especially due to the current situation of high competition in the markets with the presence of numerous new cultivars and other fruits and other foods. Low temperature has been widely used to store fruits and vegetables as its beneficial effects for delaying senescence and maintaining quality. Chilling injury (CI) is a physiological disorder induced by low, but not freezing temperatures, which affects fruit quality seriously. The increasing demand for consumption of fruits and vegetables, along with restriction on the use of synthetic chemicals, has encouraged scientific research to develop new technologies based on natural product such as salicylic acid (SA), acetyl salicylic acid (ASA), methyl salicylate (MeSA) and methyl jasmonate
(MJ). Although there are many methods to reduce CI in fruits and vegetables, salicylates and jasmonates treatments are inexpensive, easy to apply and can be used on fruits and vegetables (Asghari and Aghdam, 2010). Salicylic acid SA has been extensively used for quality improvement in a number of crops (Peng and Jiang, 2006). Literature has impressively argued the role of phenolic compounds such as salicylic acid about their influence on physiological or biochemical processes including ion uptake, membrane permeability, enzymes activity, heat production, growth development (Arberg, 1981). SA significantly reduced the quality loss in peaches (Wang et al., 2006), tomato (Ding et al., 2001), sweet peppers (Fung et al., 2004), and loquat fruits (Cai et al., 2005). SA and its derivatives are widely in use to enhance fruits postharvest life by controlling their firmness. SA has been documented to enhance flesh firmness of harvested peaches during storage (Li and Han, 1999; Wang et al., 2006), and banana fruits during ripening (Srivastava and Dwivedi, 2000). Thus, salicylic acid has remarkable ability to maintain the fruits quality during storage life of fruits. Several 
natural volatile compounds have been reported to possess antimicrobial activity and maintaining fruit quality. The methyl jasmonate (MJ) has been studied for their effectiveness in maintaining the quality of fresh fruits and vegetables. It has been reported that $\mathrm{MJ}$ treatment can reduce the development of chilling injury symptoms in zucchini (Wang and Buta, 1994) and mango (GonzalezAguilar et al., 2000). Treatment of tomato fruit with low concentrations of $(0.01 \mathrm{mM})$ methyl jasmonate (MJ) or methyl salicylate (MeSA) substantially enhanced their resistance to chilling temperature and decreased the incidence of decay during low-temperature storage. (Ding et al., 2002). The aim of this work was to study the mechanism which SA and MJ can reduce the chilling injuries and prolong the shelf life for apricot fruits.

\section{MATERIAL AND METHODS}

\section{Plant material and treatments}

Fruits from different two apricot varieties (Bergarauge and Falvor Cot) were hand harvested from the Gyümölcsért Kft. located in Boldogkőváralja, Hungary at ripe stage and selected for uniform size, colour and examined to exclude all visual defects. Each variety fruits were divided into three groups as shown in Table 1, for chemical treatment the Fruit were dipped into solution of $0.2 \mathrm{Mm}$ MeJA and $2 \mathrm{Mm}$ SA for about 15 minutes as inducing treatments and water treated fruit were control. Then each chemical treatments fruits were divided into 2 groups for storage treatment. The first group was for shelf life at $25^{\circ} \mathrm{C}$ and the fruit were examined at 4 days and 8 days after treatment. The other group of storage treatment was for storage at $1{ }^{\circ} \mathrm{C}$ and the examinations were 7,14 and 21 day after treatment. Each treatment has 3 replicats and the experiment repeated twice.

\section{Effect of SA and MJ on fruit firmness}

Fruit firmness measurements were performed on about 30 fruits immediately after harvest for each variety as zero time. Other fruits were undergone for the experimental treatments and examined subsequently in order to assess the effect of chemical treatment in reducing the stress of cold storage. The fruit firmness $\left(\mathrm{kg} \mathrm{cm}^{-2}\right)$ was measured by Magness Tazlor penetrometer.

\section{Evalaution of chilling injury and decay}

Chilling injury $(\mathrm{CI})$ and fruit decay were invistigated at the end of shelf life and cold storage, by using 30 fruit per replicate. The degree of CI was visually invistigated on the fruit surface following a double cut parallel to the axial diameter. The extent of flesh browning was divided into five classes: 0 , no browning; 1 , extensive browning covering $<25 \%$ of the cut surface; 2 , extensive browning covering $\geq 25 \%$ but $<50 \%$ of cut surface; 3 , extensive browning covering $\geq 50 \%$ but $<75 \%$ of cut surface; 4 , extensive browning covering $\geq 75 \%$ of cut surface. From this, a CI index was expressed as:

$\mathrm{CI}$ index $=[(\mathrm{CI}$ level $) \times($ number of fruit at the $\mathrm{CI}$ level $)] /$ $(4 \times$ total number of fruit in the treatment).

Symptoms of apricot fruit decay were superficial browning. The severity of the symptoms was assessed visually according to the following five-stage scale: 0 , no browning; 1 , browning covering $\geq 25 \%$ of the fruit surface; 2 , browning covering $\geq 25 \%$ but $<50 \%$ of the fruit surface; 3 , browning covering $\geq 50 \%$ but $<75 \%$ of the fruit surface; 4 , browning covering $\geq 75 \%$ of the fruit surface. From this, a decay index (DI) was expressed as:

DI index $=[($ DI level $) \times($ number of fruit at the DIlevel $)] /$ $(4 \times$ total number of fruit in the treatment).

\section{Determination of cell membrane electrolyte leakage}

Electrolyte leakage was determined using 30 disks (8 $\mathrm{mm}$ diameter, 3-4 mm thick) from flesh tissue of 5 fruits. Disks were washed with double-distilled water and then immersed in $40 \mathrm{~mL}$ double distilled water for $3 \mathrm{~h}$. Ion leakage was measured as the amount of conductivity of the solution (HANNA, Italy). Disks were boiled for $30 \mathrm{~min}$ at $95^{\circ} \mathrm{C}$, cooled in room temperature, and then the total conductivity was measured. Electrolyte leakage was expressed as relative conductivity $(100 *$ the conductivity of tissue solution/the total conductivity).

Table 1.

The design of experiment

\begin{tabular}{|c|c|c|}
\hline Chemical treatment & Storage treatment & Time of examination \\
\hline \multirow{5}{*}{ Control } & \multirow{2}{*}{ Storage at $1{ }^{\circ} \mathrm{C}$ for 15 days then at Shelf at $25^{\circ} \mathrm{C}$} & 4 days \\
\hline & & 8 days \\
\hline & \multirow{3}{*}{ Storage at $1{ }^{\circ} \mathrm{C}$} & 7 days \\
\hline & & 14 days \\
\hline & & 21 days \\
\hline \multirow{5}{*}{$0.2 \mathrm{mM}$ MeJA } & \multirow{2}{*}{ Storage at $1{ }^{\circ} \mathrm{C}$ for 15 days then at Shelf at $25^{\circ} \mathrm{C}$} & 4 days \\
\hline & & 8 days \\
\hline & \multirow{3}{*}{ Storage at $1{ }^{\circ} \mathrm{C}$} & 7 days \\
\hline & & 14 days \\
\hline & & 21 days \\
\hline \multirow{5}{*}{$2 \mathrm{mM}$ SA } & \multirow{2}{*}{ Storage at $1{ }^{\circ} \mathrm{C}$ for 15 days then at Shelf at $25^{\circ} \mathrm{C}$} & 4 days \\
\hline & & 8 days \\
\hline & \multirow{3}{*}{ Storage at $1{ }^{\circ} \mathrm{C}$} & 7 days \\
\hline & & 14 days \\
\hline & & 21 days \\
\hline
\end{tabular}




\section{Measurement of total phenol content}

Total phenol contents were determined using FolinCiocalteu's reagent according to the method of Singleton and Rossi (1965). Phenol content was calculated from a standard curve obtained by different concentrations of gallic acid.

\section{Measurement the changes in PAL activity}

\section{Fruit samples}

The samples were collected at $0,7,14$ and 21 days at $1{ }^{\circ} \mathrm{C}$ and at for shelf life after storage for 15 days at $1{ }^{\circ} \mathrm{C}$ the samples were collected after 4 and 8 days at $25{ }^{\circ} \mathrm{C}$, each treatment was replicated three times.

\section{Enzyme extract}

Flesh $(10 \mathrm{~g})$ from 10 fruits with $0.5 \mathrm{~g}$ PVPP was ground with $25 \mathrm{ml}$ of $50 \mathrm{mmol} \mathrm{l}^{-1}$ sodium borate buffer (pH 8.8, containing $5 \mathrm{Mm} \beta$-mercaptoethanol) for phenylalanine ammonia-lyase (PAL). The extracts were then homogenized and centrifuged at $10000 \times \mathrm{g}$ for 20 min at $4{ }^{\circ} \mathrm{C}$ the supernatant were used for enzyme assay.

PAL activity was assayed according to the method of Assis et al. (2001), with slight modifications. Enzyme extract $(1 \mathrm{ml})$ was incubated with $2 \mathrm{ml}$ of borate buffer $\left(50 \mathrm{mmol} \mathrm{l}^{-1}, \mathrm{pH} 8.8\right)$ and $1 \mathrm{ml}$ of L-phenylalanine $\left(20 \mathrm{mmol} \mathrm{l}^{-1}\right)$ for $60 \mathrm{~min}$ at $37^{\circ} \mathrm{C}$. The reaction was stopped with $1 \mathrm{ml} \mathrm{HCl}\left(1 \mathrm{~mol} \mathrm{l}^{-1}\right)$. PAL activity was determined by the production of cinnamate, which was measured by absorbance at $290 \mathrm{~nm}$. The blank was the crude enzyme preparation mixed with L-phenylalanine with zero time incubation. PAL activity was defined as nmol cinnamic acid $\mathrm{h} \mathrm{mg}^{-1}$ protein.

\section{Data analysis}

Experiments were performed using a completely randomized design. All analyses were performed with SPSS program (SPSS Inc., Chicago, IL, USA). The data were analyzed by one-way analysis of variance (ANOVA). Means separation was performed by Duncan's multiple range tests. Differences at $\mathrm{p}<0.05$ were considered as significant.

\section{RESULTS}

\section{Effect of SA and MJ in keeping fruit firmness of apricot fruits}

Data in Figure 1 shows that the fruit firmness was reduced in all treated fruit and this reduction was obvious in water treated fruit. The SA and MJ treated fruit showed lower reduction in firmness. The differences between chemical treated fruit either SA or MJ and the control fruit was significant $(\mathrm{p}<0.05)$. Also it is clear that $\mathrm{MJ}$ achieved lower softening in comparison to SA treated fruit without significant. For differences between varieties, the data shows that Flavor Cot has appearance to keep it firmness during storage better that Bergarauge. These results showed that the SA and MJ prolong the shelf life of apricot fruit at $25{ }^{\circ} \mathrm{C}$ either for Flavor Cot and Bergarauge with highly differences with water treated fruit $(\mathrm{p}<0.05)$.
Figure 1: The effect of $\mathbf{2} \mathbf{m M}$ salicylic acid and $0.2 \mathrm{mM}$ methyl Jasmonic acid on fruit firmness $\left(\mathrm{Kg} \mathrm{cm}^{-2}\right)$
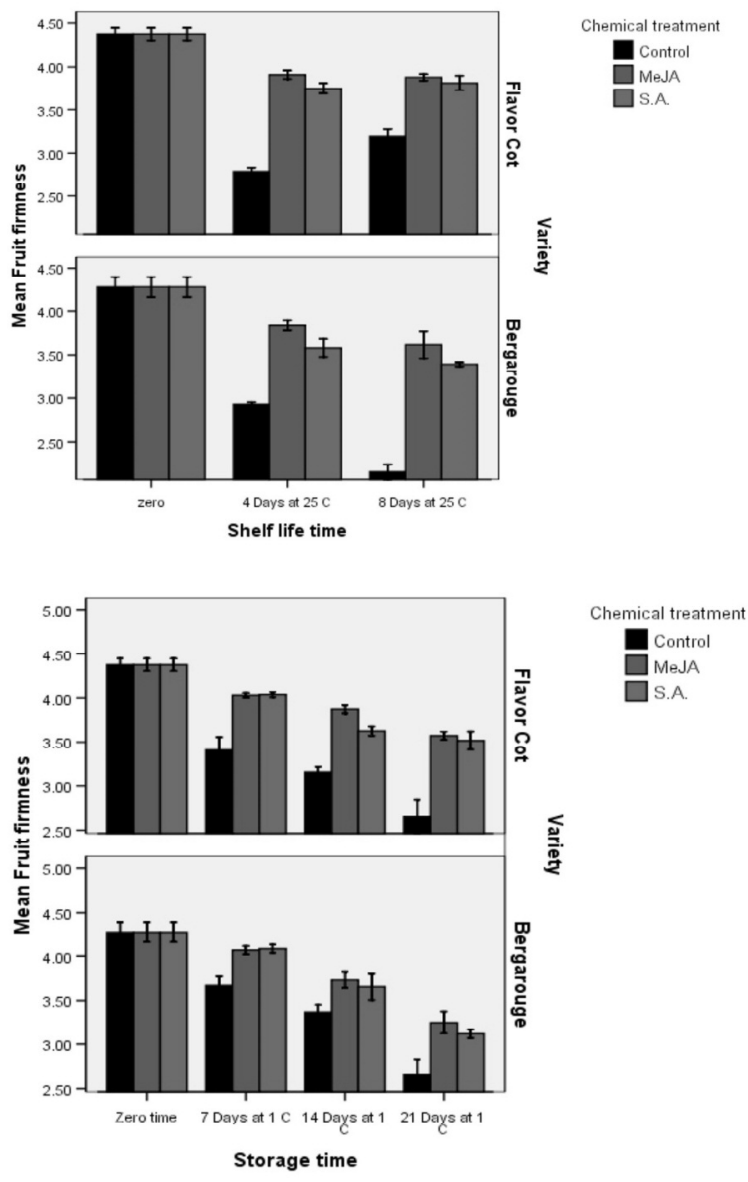

Effect of SA and MJ in chilling injury and decay index

The degree of chilling injury $\mathrm{CI}$ of control, $\mathrm{MJ}$ and SA treatments increased with storage time as observed by the CI index (Table 2). Meanwhile, pre-treated fruit with $0.2 \mathrm{Mm} \mathrm{MJ}$ and $2 \mathrm{Mm}$ SA achieved low CI index than control $(\mathrm{p}<0.05)$ in all storage times and no differences was noticed for the tested varieties. The data in Table 2 showed that Bergarauge has higher resistance to chilling than flavor cot and these differences were significant at 14 and 21 days of storage at $1{ }^{\circ} \mathrm{C}$. The shelf life data showed that the $\mathrm{Cl}$ increase dramatically after fruit expose to room temperature and SA and MJ treated fruit showed good resistance to these symptoms than control in tested two varieties with significant differences.

As can be seen in Table 3, non treated apricot fruit (control) showed dramatically increase in decay $\%$ at $1{ }^{\circ} \mathrm{C}$ as reached to $96.25 \pm 2.3 \%$ and $98.23 \pm 3.21 \mathrm{a} \%$ after 21 days for Bergarauge and Flavor cot respectively. Whereas $0.2 \mathrm{Mm}$ MJ and $2 \mathrm{Mm}$ SA treatments depressed the development of fruit decay with significant different with control $(p<0.05)$. MJ and SA showed obvious effect in keeping the apricot fruit away from fruit decay in shelf life treatments. Flavour cot fruit showed highly resistance to decay symptoms than Bergarauge with significant differences $(\mathrm{p}<0.05)$. 
The effect of MJ and SA treatments on resistance of apricot fruits to chilling stress

\begin{tabular}{|c|c|c|c|c|c|c|}
\hline \multirow[b]{2}{*}{ Treatment } & \multirow[b]{2}{*}{ Varieties } & \multicolumn{5}{|c|}{ CI index $(\%)$} \\
\hline & & 7 days at $1{ }^{\circ} \mathrm{C}$ & 14 days at $1{ }^{\circ} \mathrm{C}$ & 21 days at $1{ }^{\circ} \mathrm{C}$ & $\begin{array}{l}15 \text { days at } 1{ }^{\circ} \mathrm{C} \text { then } \\
4 \text { days at } 25^{\circ} \mathrm{C}\end{array}$ & $\begin{array}{l}15 \text { days at } 1{ }^{\circ} \mathrm{C} \text { then } \\
8 \text { days at } 25^{\circ} \mathrm{C}\end{array}$ \\
\hline \multirow{2}{*}{ Control } & Bergarouge & $3.12 \pm 0.87 \mathrm{a}$ & $16.68 \pm 1.45 \mathrm{a}$ & $37.65 \pm 4.56 \mathrm{a}$ & $18.67 \pm 2.35 \mathrm{a}$ & $30.24 \pm 3.65 \mathrm{a}$ \\
\hline & Flavor Cot & $3.21 \pm 0.541 \mathrm{a}$ & $19.23 \pm 0.351 \mathrm{a}$ & $44.21 \pm 2.351 \mathrm{a}$ & $20.12 \pm 2.65 \mathrm{a}$ & $30.12 \pm 4.02 \mathrm{a}$ \\
\hline \multirow{2}{*}{$0.2 \mathrm{Mm}$ MeJA } & Bergarouge & $1.35 \pm 0.21 \mathrm{a}$ & $4.52 \pm 1.98 \mathrm{c}$ & $9.68 \pm 3.65 \mathrm{~d}$ & $8.65 \pm 1.09 b$ & $14.35 \pm 1.35 \mathrm{c}$ \\
\hline & Flavor Cot & $2.32 \pm 1.01 \mathrm{a}$ & $6.21 \pm 1.68 b$ & $11.21 \pm 1.02 b$ & $10.21 \pm 2.32 b$ & $17.21 \pm 2.31 b$ \\
\hline \multirow{2}{*}{$2 \mathrm{Mm} \mathrm{SA}$} & Bergarouge & $1.64 \pm 0.34 \mathrm{a}$ & $5.58 \pm 0.68 \mathrm{c}$ & $20.91 \pm 5.09 \mathrm{c}$ & $7.68 \pm 2.34 b$ & $19.26 \pm 2.65 b$ \\
\hline & Flavor Cot & $1.54 \pm 0.21 \mathrm{a}$ & $5.21 \pm 0.98 \mathrm{~b}$ & $21.24 \pm 2.032 \mathrm{c}$ & $9.21 \pm 1.32 \mathrm{~b}$ & $19.24 \pm 1.23 b$ \\
\hline
\end{tabular}

Note: values within a column followed by different letters are significantly different at $\mathrm{p}<0.05$ according to Duncan's multiple range tests. The results represent the means $\pm \mathrm{SD}$ of triplicate assay.

Table 3

The effect of MJ and SA treatments on resistance of apricot fruits to decay

\begin{tabular}{|c|c|c|c|c|c|c|}
\hline \multirow[b]{2}{*}{ Treatment } & \multirow[b]{2}{*}{ Varieties } & \multicolumn{5}{|c|}{ Fruit decay $(\%)$} \\
\hline & & 7 days at $1{ }^{\circ} \mathrm{C}$ & 14 days at $1{ }^{\circ} \mathrm{C}$ & 21 days at $1{ }^{\circ} \mathrm{C}$ & $\begin{array}{l}12 \text { days at } 1{ }^{\circ} \mathrm{C} \text { then } \\
4 \text { days at } 25^{\circ} \mathrm{C}\end{array}$ & $\begin{array}{l}12 \text { days at } 1{ }^{\circ} \mathrm{C} \text { then } \\
8 \text { days at } 25^{\circ} \mathrm{C}\end{array}$ \\
\hline \multirow{2}{*}{ Control } & Bergarouge & $16.05 \pm 1.07 \mathrm{a}$ & $56.24 \pm 5.35 \mathrm{a}$ & $96.25 \pm 2.3 \mathrm{a}$ & $66.36 \pm 2.65 \mathrm{a}$ & $100 \pm 3.05 \mathrm{a}$ \\
\hline & Flavor Cot & $13.25 \pm 1.32 \mathrm{a}$ & $40.21 \pm 3.25 a$ & $98.23 \pm 3.21 \mathrm{a}$ & $52.12 \pm 4.21 b$ & $96.23 \pm 2.32 \mathrm{a}$ \\
\hline \multirow{2}{*}{$0.2 \mathrm{Mm}$ MeJA } & Bergarouge & $2.11 \pm 0.98 b$ & $6.57 \pm 1.08 \mathrm{~b}$ & $16.98 \pm 6.65 b$ & $16.35 \pm 3.65 \mathrm{c}$ & $36.65 \pm 2.03 b$ \\
\hline & Flavor Cot & $2.01 \pm 0.32 \mathrm{~b}$ & $6.21 \pm 1.22 b$ & $14.21 \pm 1.23 \mathrm{~b}$ & $12.35 \pm 1.21 \mathrm{c}$ & $31.23 \pm 3.01 \mathrm{~b}$ \\
\hline \multirow{2}{*}{$2 \mathrm{Mm} \mathrm{SA}$} & Bergarouge & $2.33 \pm 1.03 \mathrm{~b}$ & $7.58 \pm 2.08 \mathrm{~b}$ & $15.61 \pm 4.19 b$ & $20.36 \pm 4.09 \mathrm{c}$ & $35.36 \pm 3.65 b$ \\
\hline & Flavor Cot & $2.12 \pm 1.021 \mathrm{~b}$ & $6.35 \pm 1.32 b$ & $13.21 \pm 2.01 \mathrm{~b}$ & $15.12 \pm 2.31 \mathrm{~d}$ & $35.26 \pm 2.01 \mathrm{~b}$ \\
\hline
\end{tabular}

Note: values within a column followed by different letters are significantly different at $\mathrm{p}<0.05$ according to Duncan's multiple range tests. The results represent the means $\pm \mathrm{SD}$ of triplicate assay.

\section{Cell membrane electrolyte leakage}

The cell membrane electrolyte leakage exceeded to about $100 \%$ in water treated fruit while SA and MJ could reduce cell membrane electrolyte leakage in apricot fruits stored for 14 and 21 days. But when fruits were transported from low temperature to room temperature for shelf life, membrane electrolyte leakage increased and there was no significant difference between MJ treated and SA fruits while control fruit showed dramatically increasing (Figure 2). The same trend was noticed for the tested varieties.

\section{Effect of SA and MJ on total phenol content}

Total phenol content reduced sharply in water treated fruit after storage at 7 days meanwhile, MJ treated fruit showed slight increase in fruit phenol content with significant differences with control fruit but after 14 days of storage at $1{ }^{\circ} \mathrm{C}$ the phenols content took to decrease but still higher than control fruit $(\mathrm{p}<0.05)$ for Bergarauge fruits (Figure 3). At the same time, SA treated fruit achieved semi stable phenol content during first 2 weeks then decreased in either Bergarauge or Falvor cot. The differences between the varieties were not significant but phenol content of flavour cot fruit was higher than Bergarauge.

\section{Effect of SA and MJ on PAL activity}

Treated fruit with SA and MJ showed increasing in PAL activity during 7, 14 and 21 days at $1{ }^{\circ} \mathrm{C}$ (Figure 4). At the same time water treated fruit showed sharply decreasing in PAL activity. MJ treated fruit showed priority than those treated with SA with significant in case of Bergarauge fruit. For the differences between varieties, Bergarauge fruit showed high response to SA or MJ treatment than flavour cot with significant differences. Fruit at room temperature was affected by SA and MJ, as the PAL activity start to increase slightly at 4 days at $25^{\circ} \mathrm{C}$ then the fruit treated with $\mathrm{MJ}$ increased significantly than SA treated fruits for Bergarauge fruit. Also SA and MJ enhanced the PAL activity of Flavor cot but it was lower response than Bergarauge fruit.

\section{DISCUSSION}

In this work, during cold storage and further shelf life at $25{ }^{\circ} \mathrm{C}$ of control apricot, the loss of firmness occurred gradually along storage. The reduction in softening process being retarded by the use of both MJ and SA treatments. it has been postulated that $\mathrm{MJ}$ reduces pectinmethylesterase (PME) activity, decreasing deesterification of pectin (Meng et al., 2009), and thus maintaining fruit texture. SA has been documented to enhance flesh firmness of harvested peaches during storage (Li and Han, 1999; Wang et al., 2006), and banana fruits during ripening (Srivastava and Dwivedi, 2000). Thus, SA has remarkable ability to maintain the fruits quality during storage life of fruits and these results in the same way like our finding (Figure 2). Other face of $\mathrm{MJ}$ mode of action on affecting is decreasing membrane lipid peroxidation and maintaining high superoxide dismutase (SOD) activity in strawberry under water stress (Wang, 1999). 
Figure 2: The effect of $\mathbf{2} \mathbf{m M}$ salicylic acid and $0.2 \mathrm{mM}$ methyl Jasmonic acid on membrane electrolyte leakage (\%)
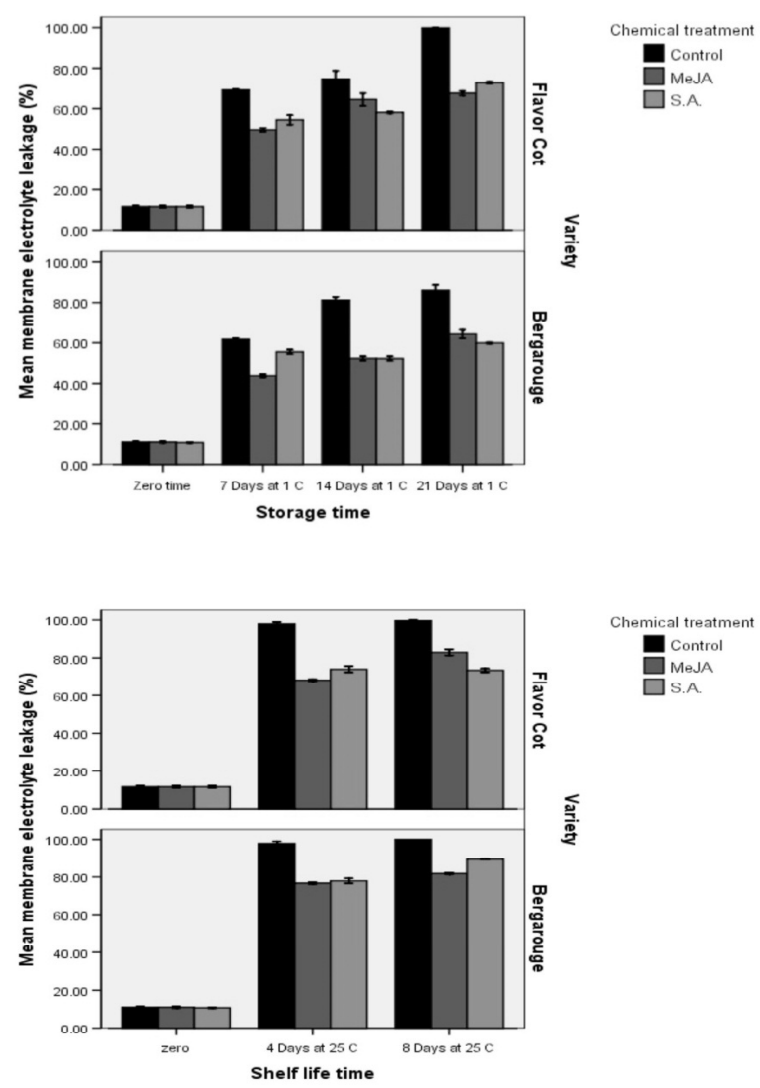

Figure 3: The effect of $\mathbf{2} \mathbf{~ m M}$ salicylic acid and $0.2 \mathrm{mM}$ methyl Jasmonic acid Total phenol (mg GAE $100 \mathrm{~g} \mathrm{FW}^{-1}$ )
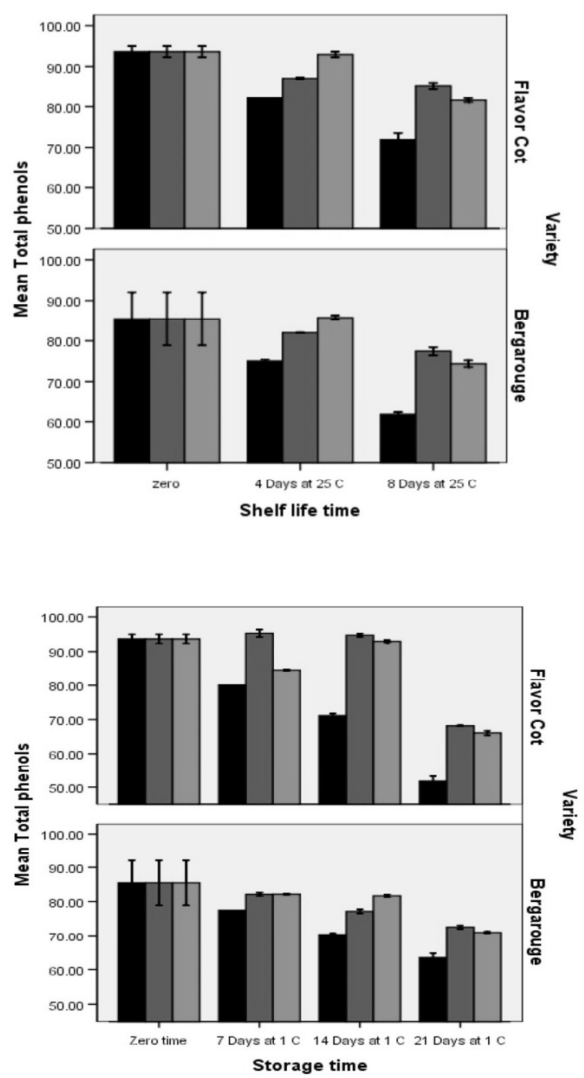

Figure 4: The effect of $\mathbf{2} \mathbf{~ m M}$ salicylic acid and $\mathbf{0 . 2} \mathbf{~ m M}$ methyl Jasmonic acid on PAL activity ( $\left.\mathrm{nmol} \mathrm{h}{ }^{-1} \mathrm{mg}_{\text {protein }}{ }^{-1}\right)$
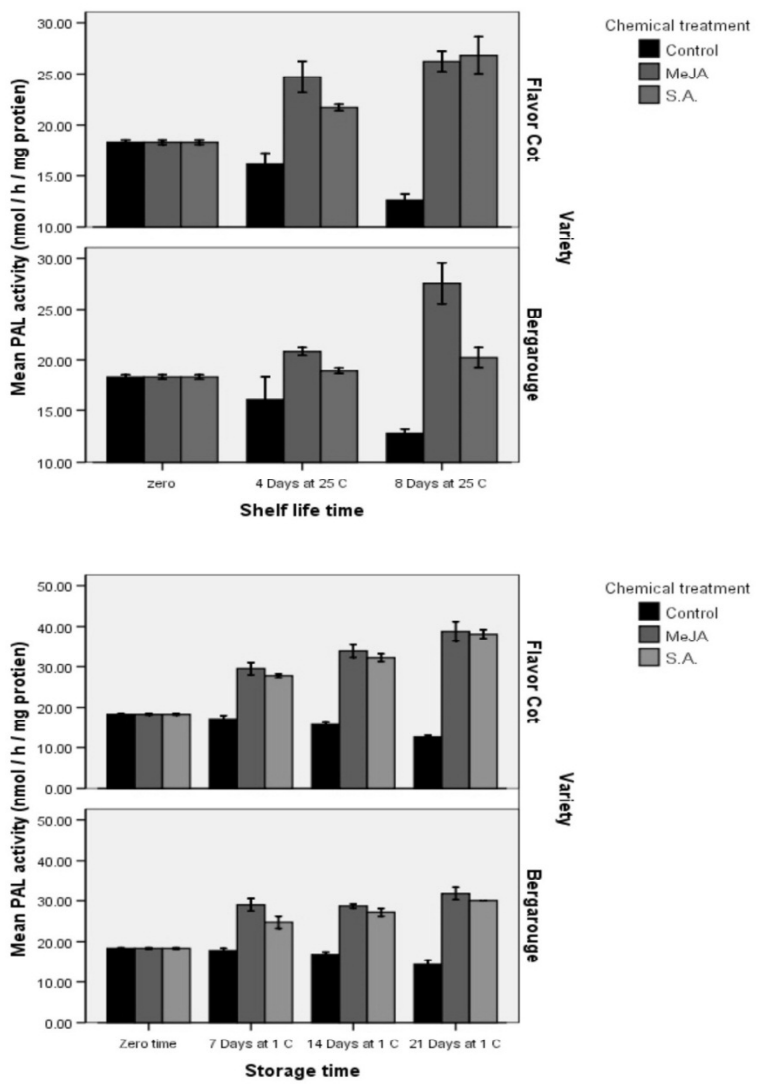

Our data demonstrated that the treatment of apricot fruit with methyl jasmonate (MJ) or salicylate (SA) substantially enhanced their resistance to chilling temperature and decreased the incidence of decay during low-temperature storage and shelf life.

Apricot fruit easy appear chilling injury when stored at low temperature. The CI symptoms was generally influenced and triggered by a combination of storage temperature and period ( $\mathrm{Li}$ and Han, 1999). Our results state that using of MJ and SA play important role in alleviating CI symptoms. However MJ could to keep the $\mathrm{CI}$ at lowest level in comparison with $\mathrm{SA}$ treatment after 21 days at $1{ }^{\circ} \mathrm{C}$ and after 8 days at $25^{\circ} \mathrm{C}$. It has been reported that the improvement of chilling tolerance in harvested horticultural crops is related to enhancement in activities of antioxidant enzymes. Sala (1998) found that the chilling-tolerant mandarins have a higher antioxidant enzyme activity than the chilling sensitive cultivars. This may interpret why MJ and SA is acting its role better in cold storage than shelf life (Table 2) may be because the chilling as kind of stress work as an inducer to express some important antioxidant genes as reported by Fung et al 2004 as they demonstrated that the expression patterns of alternative oxidase and seven other genes involved in defenses against oxidative streets in pepper fruit treated with MeSA or MJ vopor increased transcript level of these enzymes even at room chamber of $25^{\circ} \mathrm{C}$, whereas no changes was observed with untreated and this was joined with preventing chilling injury. 
MJ has been shown to induce the synthesis and expression of some stress proteins such as heat-shock proteins and pathogenesis-related proteins, which lead to the increased resistance of the stress and the decreased incidence of the decay (Ding et al., 2001; 2002). In this experiment, lower cell membrane electrolyte leakage was also found in MJ treated fruits (Figure 1), indicating the less disruption in plasma membrane under chilling $\backslash$ stress. Thus, it is suggested that maintaining membrane integrity by SA and MJ treatment was beneficial for controlling flesh browning of peach fruits.

The activity of PAL was examined in this study to investigate the possible role of PAL in phenolic metabolism of apricot fruit in response to $\mathrm{MJ}$ treatment We found that fruit treated with MJ exhibited significantly higher levels of PAL activity, total phenolics, compared to the control fruit. These results suggest that MJ may improve the antioxidant status of apricot fruit by inducing PAL activity and thus positively affecting phenolic metabolism.

Some papers demonstrated that the SA play a vital role in induction of systematic acquired resistance in plant cells by its ability to induce defense and antioxidant enzymes such as polyphenoloxidase (PPO), phenylalanine ammonia lyase (PAL) and $\beta$-1, 3-glucanase (Qin et al 2003).

\section{REFERENCES}

Arberg, B. (1981): Plant growth regulators. Monosubstituted benzoic acid. Swedish Journal Agricultural Research. 11: 93-105.

Asgharia, M.-Aghdam, M. S. (2010): Impact of salicylic acid on post-harvest physiology of horticultural crops. Trends in Food Science and Technology. 21: 502-509.

Assis, J. S.-Maldonado, R.-Mnoz, T.-Escribano, M. I.-Merodio, C. (2001): Effect of high carbon dioxid concentration on PAL activity and phenol content in ripening cherimoya fruit. Postharvest Biology and Technology. 23: 33-39.

Cai, C. X. Li-Chen, K. S. (2005): Acetylsalicylic acid alleviates chilling injury of postharvest loquat (Eriobotrya japonica Lindl.) fruit. Eur. Food Res. Technol. 223: 533-539.

Ding, C. K.-Wang, C. Y.-Gross, K. C.-Smith, D. L. (2001): Reduction of chilling injury and transcript accumulation of heat shock protein genes in tomatoes by MJ and MeSA. Plant Sci. 161: 1153-1159.

Ding, C. K.-Wang, C. Y.-Gross, K. C.-Smith, D. L. (2002): Jasmonate and salicy - late induce the expression of pathogenesis - relatedprotein genes and increase resistance to chilling injury in tomato fruit. Planta. 214: 895-901.

Fung, R.-Wang, C.-Smith, D.-Gross, K.-Tian, M. (2004): MeSA and MJ increase steady-state transcript levels of alternative oxidase and resistance against chilling injury in sweet peppers (Capsicum annuum L.). Plant Sci. 166: 711-719.

Gonz'alez-Aguilar, G. A.-Fortiz, J.-Cruz, R.-B'aez, R.-Wang, C. Y. (2000): Methyl jasmonate reduces chilling injury and maintains postharvest quality of mango fruit. J. Agric. Food Chem. 48: 515519
Li, L. P.-Han, T. (1999): The effects of salicylic acid in the storage of peach. Food Sci. 7: 61-63.

Meng, X.-Han, J.-Wang, Q.-Tian, S. (2009): Changes in physiology and quality of peach fruits treated by methyl jasmonate under low temperature stress. Food Chemistry. 114: 1028-1035.

Peng, L.-Jiang, Y. (2006): Exogenous salicylic acid inhibits browning of fresh-cut Chinese water chestnut. Food Chem. 94: 35-540.

Qin, Q. Z.-Tian, S. P.-Xu, Y.-Wan, Y. K. (2003): Enhancement of biocontrol efficacy of antagonistic yeasts by salicylic acid in sweet cherry fruit. Physiol. Mol. Plant Patho. 62: 147-154.

Sala, J. M. (1998): Involvement of oxidative stress in chilling injury in cold-stored mandarin fruits. Postharvest Biology and Technology. 13: 255-261.

Singleton, V. L.-Rossi J. A. (1965): Colorimetry of total phenolics withphospho molybdic phosphotungstic acid „reagents”. Am. J. Enol. Vitic. 16: 144-158.

Srivastava, M. K.-Dwivedi, U. N. (2000): Delayed ripening of banana fruit by salicylic acid. Plant Sci. 158: 87-96.

Wang, C. Y.-Buta, J. G. (1994): Methyl jasmonate reduces chilling injury in Cucurbita pepo through its regulation of abscisic acid and polyamine levels. Environ. Exp. Bot. 34: 427-432.

Wang, L.-Chena, S.-Kong, W.-Li, S.-Archbold, D. D. (2006): Salicylic acid pretreatment alleviates chilling injury and affects the antioxidant system and heat shock proteins of peaches during cold storage. Postharvest Biol. and Technol. 41: 244-251.

Wang, S. Y. (1999): Methyl jasmonate reduces water stress in strawberry. Journal of Plant Growth Regulation. 18: 127-134. 